\title{
高空氣流の狀況觀測 と其考察
}

關 根 幸 雄

緒言 所澤で測風氣球に上る氣流觀測を開始しくから十年以上になるが、每日使

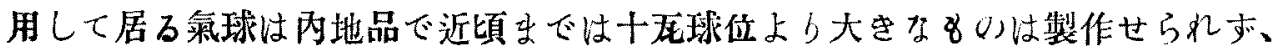
刃たとへ重量は重くとも8るくてそれ程效果のかい8のばかbであつた。をれで

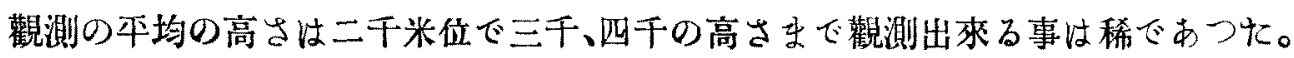

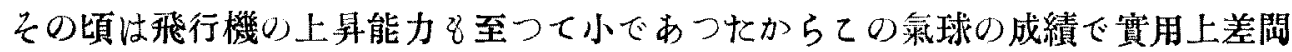

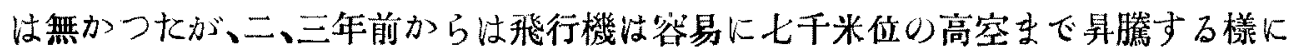
なつて二干米の成績では望用上から8满足が出永るくなつた。そてで佛國品を見 本々して氣球製作所へ試作を依賴した。大正九年頃に四○无の測風氣球が出來て、 之を使用して一尔間百五十米或は二百米の身䭻力を與て可視度良好なる日を撰ん で觀測した。大正十年の始奻ら大正十一年九月をで觀測を繼續し稍々不满足を 醫するに足る成績を得て。てれを統計して諸賢の御參考心資したいと考へます。

\section{觀漕}

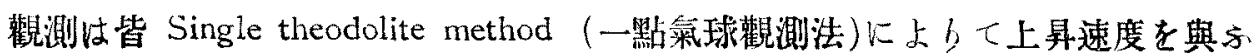

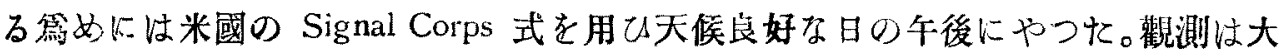
多數で全觀測內三干米以上觀測せる八一回を統計した。

測風氣球の觀測成緼を統計する場合に起てる缺點々して中層の三干四千位迄は 数多くあれ共高空に至るに随つて次第に減少して七干米乃至七千五百米に至て㯵 かに五、六间とるる。

Single theodolite method К上る觀測成績の精度に就さ恃多くの疑問8まる事 ではあるが、大正十一年の集誌に大石高層臺長及堀口技師が御研究の結果舜表 せられて居る此狆に上れば『近似的に值を得る』と云ふ事注出來る。

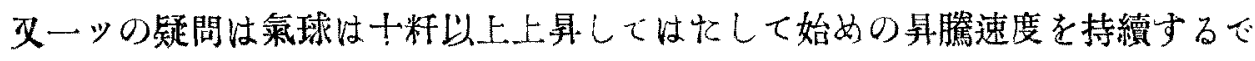

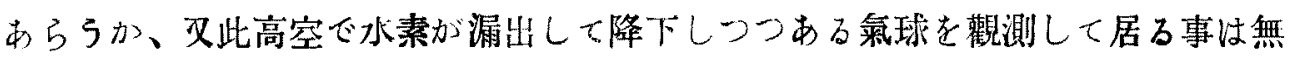
かららか、等の疑問を持つたが、幸に本年一月のQuarterly Journal of the Royal meteorological society K N.K. Johnson 氏が The Beheviour of pilot-Ballons at great heights 
として詳しい實驗が記載してある。てれによると高空に年るに隨つて少しづ、上 舁速度が增加するが水素の leackage 々相籼して極めてわすかか上昇速度を增し等 速度上身として差閭なき事、及二萬呎以下るらば水素恃氣球に小孔が出來て其處

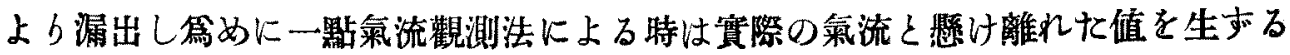
盧れ無き事等を記載してある。强さを試驗して見ると新しい製品は英國製九○时 三五死球に比してそれ程棌色ある共見え奴。そてで七千米の高さまで統計して報 告する事にする。

觀測は三干米以上の高度迄達した八十一间の成績を統計した 8ので月別にしま すと次の如くであります。

\begin{tabular}{|c|c|c|c|c|c|c|c|c|c|c|c|c|c|}
\hline 月 & 一月 & 二月 & 三月 & 四月 & 五月 & 六月 & 七月 & 八月 & 九月 & 十月 & 十一月 & 十月 & 年 \\
\hline 淮測尼數 & 6 & 9 & 5 & 7 & 5 & 5 & 4 & 7 & 9 & 13 & 17 & 2 & 81 \\
\hline
\end{tabular}

\section{成績}

第一表は五百米每の平均風速、本均方向、頻度百分率及觀測回數を表注し第一圖 は平均風速百米每の平均起結じ付けた線と平均曲線とを示し第二圖柱上空の氣流 を圖示した8のである。

第 一 表 所澤上空氣流狀況

\begin{tabular}{|c|c|c|c|c|}
\hline 度 & 風 & 本均方向 & 類 & 萑涀 回 数 \\
\hline 0 * & 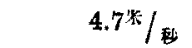 & $\mathrm{N} 12^{\circ} \mathrm{E}$ & $12 \%$ & 81 \\
\hline 500 & 4.2 & $\mathrm{~N} 65^{\circ} \mathrm{E}$ & $17 \%$ & 81 \\
\hline 1000 & 2.8 & $\mathrm{~N} 88^{\circ} \mathrm{W}$ & $14 \%$ & 81 \\
\hline 1500 & 4.8 & $\mathrm{~N} 70^{\circ} \mathrm{W}$ & $36 \%$ & 81 \\
\hline 2000 & 5.8 & N69 $69^{\circ}$ & $57 \%$ & 81 \\
\hline 2500 & 7.8 & $N 74^{\circ} \mathrm{W}$ & $63 \%$ & 81 \\
\hline 3000 & 9.8 & $\mathrm{~N} 77^{\circ} \mathrm{W}$ & $70 \%$ & 81 \\
\hline 3500 & 9.4 & $\mathrm{~N} 79^{\circ} \mathrm{W}$ & $54 \%$ & 40 \\
\hline 4000 & 8.1 & $\mathrm{~S} 81^{\circ} \mathrm{W}$ & $47 \%$ & 29 \\
\hline 4500 & 9.7 & $\mathbf{S} 83^{\circ} \mathbf{W}$ & $52 \%$ & 23 \\
\hline 5000 & 11.5 & $\mathrm{~S} 70^{\circ} \mathrm{W}$ & $68 \%$ & 18 \\
\hline 5500 & 14.1 & $\mathrm{~S} 88^{\circ} \mathrm{W}$ & $66 \%$ & 14 \\
\hline 6000 & 18.9 & $\mathrm{~S} 88^{\circ} \mathrm{W}$ & $72 \%$ & 13 \\
\hline 6500 & 20.8 & $S 75^{\circ} \mathrm{W}$ & $71 \%$ & 11 \\
\hline 7000 & 19.3 & $\mathrm{~S} 83^{\circ} \mathrm{W}$ & $60 \%$ & 6 \\
\hline
\end{tabular}



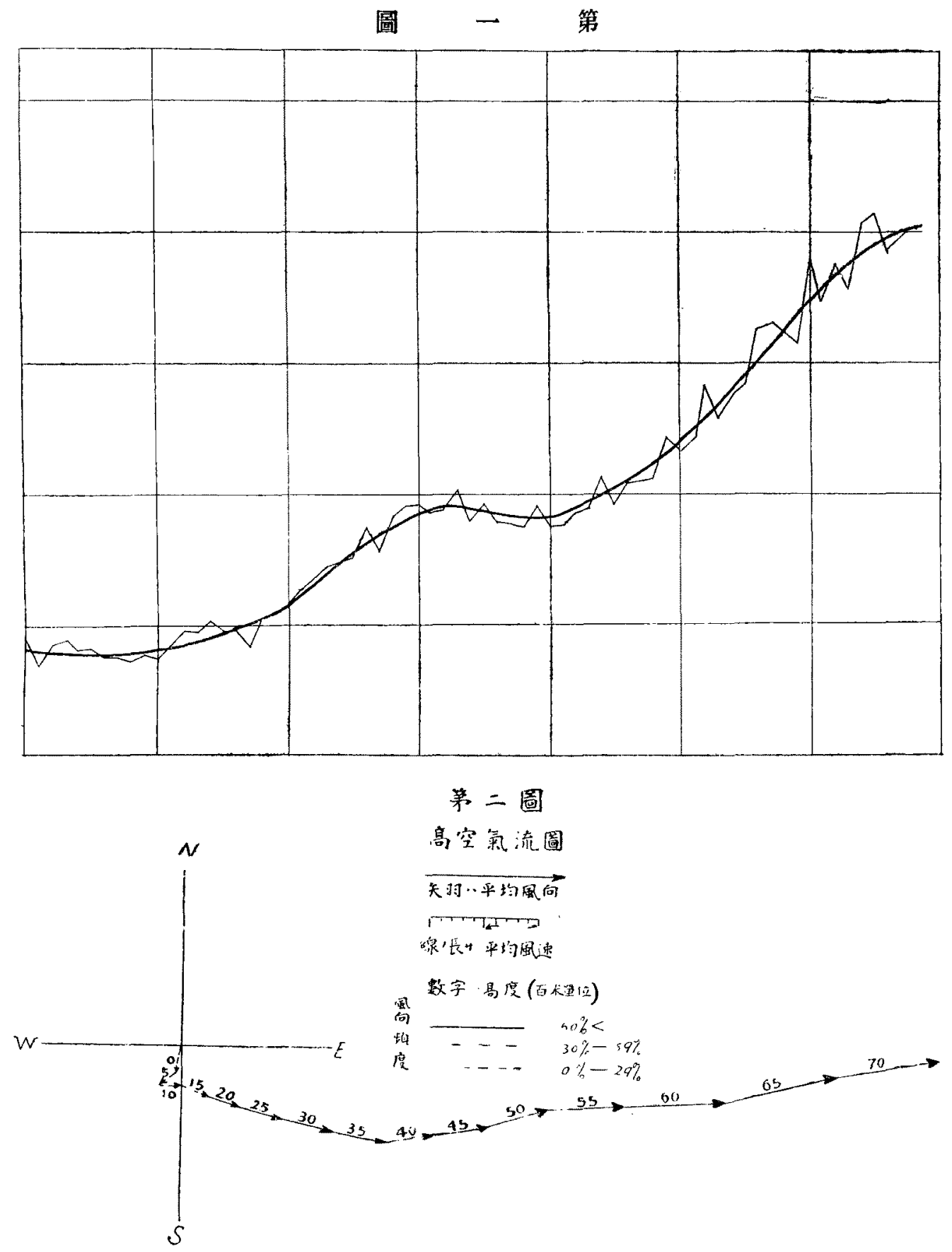

\section{高空の氣流に關する考察}

A、以上に記した氣流の状況から觀察すると、地上から千五百米の風系と千无百 米上b四千米范の風系及四千米以上の風系との三つに區別する事が出秝さらで 
ある。地上から千五百米迄の高度心゙は信風、海陸風、太陽風等其他地方的る風 向の變化に䒆されて極为て不定る8のとなつて居る。千五百米以上にるると多 くの場合西風に九る。此の西風に變る高度は季節と特刻によって異るる8ので 所澤にての五筒年間の每日三回定時觀測の統計に上ると、冬の六特では九百米 十特では千米十四時では千米で夏にては六時で千五百米十特で千五百米十四時 だ千六百米になる(本誌第四○年第九號照)。

B、干五百米以上四千米迄の高度には西風は卓越して居る平均速度は十尔た 平均風向は北七十五度西師ち偏北西風である。

岡田先生が明治四十四年に練習生に講義せられけ筆記によると北緯三十五度の 上空二干乃至四干の高度では Return Current が卓越し其方向は偏北西風であ る。此れは博士の氣象學講話に8同㧼る語明である。丁度之れを此の国歸流々 考へると一致する。其後 H. Hildebrand Hildebrandson の大循環に關する須 が Mo-nthry 誌の一九一九年六月號に發表せられ藤原博士は集誌に翻摆記載せ られた。此れによると们赤道の上空で卓越する東風が北牛球では次第に南東流

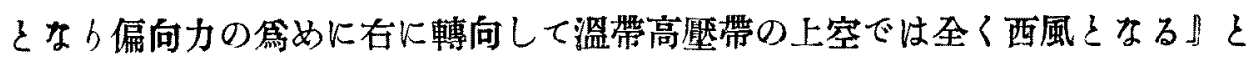
ある、さらすれば反對貿易風は四○度以上の緯度の地方の上空では全く流行せ ホ、從つて回歸流は無いとすれば此の氣流は何んであるか甚え゙疑問である、少

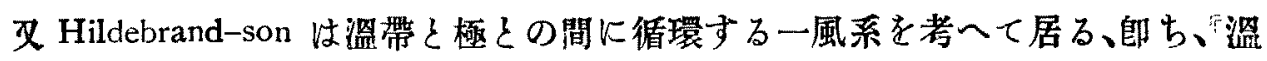
带高壓带と極地々の間に一つの循環は行はれて、北牛球の下層では南西風々な り上層では北西流とみつて溫带無風帶にては下降流となら上茎は西風とるる』

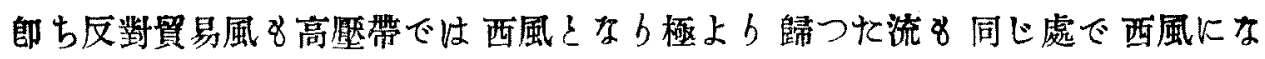
る。此等によりて考ふるに我々の上空では極より歸つた流は全くの西風とから 秋にして幾分南の分力を保有して偏北西風とかつて居るのでねから5かと考人 る。其偏北西風は此の氣流ではあるまいか。

C、氣流圖を見ると四千米にて急に風向が變つて西風ではするが幾分北の分力を 有して風向から云ふと南七十五度西の風が七千の高空では二十米酸本均に吹い て居る。四千米位の高度では丁度風向變曲點であつて頻度の百分率8 本均風速 8 減少して居る。此の四千米以上の風系を考查するに Ferrel の珫に從へば反對 
貿易風であら5 Hildbrandson の新説によれば緯磨三十五度の高層では反對財 易風恃西風であらねばなら如。此の風系は售北の分力有して居る所から考へ ると、反對貿易風恬我々の上空では西風にはるら切らんで幾分北に進し分力を 有して極から歸つせ氣流の上を流れて居るのではるかららかと想はれる。

\section{D、季節風の影響}

地上に於ては所澤地方は「・モンスーンの影響の䉆めに大循環系統を䍌知する事 は勿論出隶難いが私は「モンスーン」の影㗽する高度に就いて多くの疑問を有し て居る。移動性高氣壓に付きては別であるが、冬の信風が烈しく吹き大陸地方つ

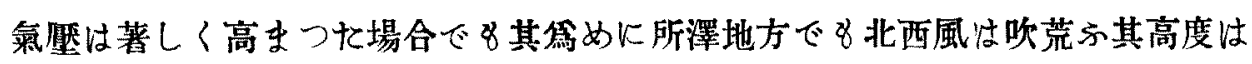
干米附近に於て最强で二干米迄の高度の或る處で性急に西風に轉向するのは普 通にて三千米迄信風の勢力の及ぶ事は極为て稀である。此れは常に私の經駩し

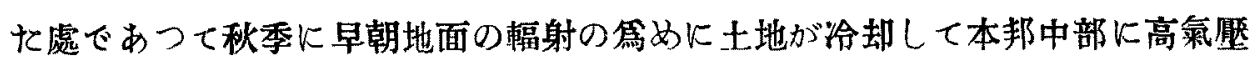
が生ずる。地上では吹き出す風が觀測せらるくが其高度忙百米位であつて低さ は三干米位の高さの8のさい出る徐家䌭での觀測で8「モンスーン」の達する 高度はさして高くるい栚に記戴してある。此等によつて考查するに三千米以上 の氣流はさして「モンスーン」の影響を受けて居らないので加ら5かと考へ ます、淺學非才にて充分小る考查して斷定する事怯出來かいが諸先生方の御筩 正に上万て其風系る察したいる考へます何卒御教示者賜らてい、筆を擱くに際 して此等の觀測に就さては岩本先生の御指道索受け考察に關しては藤原先生の

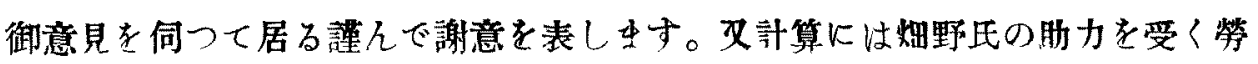
を謝す。

\section{(大正十一年十一月甘九日夜 所澤にて)}

\section{Summary of Pilot Balloon Observations at} Tokorozawa. (Abstruct) by Y. Sekine.

At Aerodrome of Military Aviation School Tokorozawa Japan,( N35 4 $48^{\prime}$ E130 $28^{\prime}$ ) pilot balloon observation with single theodlite and with $40 \mathrm{gr}$ balloons were made from January 1921 to Sept. 1922. The author used the results of 81 reliable ascentions and obtaind avernge wind velocity-as shown in Fig 1 -and wind directions-Fig. 2 at this place. The result affirms the prevailance of great westerlies at heights above1500.m. According to the author's opinion, the height of monsoon in this region is limitted under $1500 \mathrm{~m}$. and above which the return current prevailes until $4000 \mathrm{~m}$. and thence upward antitrade still has it slight notherly compornent. 